\title{
A melanoma malignum előfordulása krónikus limfocitás leukémiás betegekben
}

\author{
Korom Ágnes ${ }^{1, @}$, Csányi Ildikó ${ }^{2}$, Baltás Eszter ${ }^{2}$, Oláh Judit ${ }^{3}$, Borbényi Zita ${ }^{1}$, \\ Gurbity Pálfi Tímea ${ }^{4}$ \\ ${ }^{1}$ Szegedi Tudományegyetem, II. sz. Belgyógyászati Klinika és Kardiológiai Központ, Szeged \\ ${ }^{2}$ Szegedi Tudományegyetem, Bőrgyógyászati és Allergológiai Klinika, Szeged \\ ${ }^{3}$ Szegedi Tudományegyetem, Onkoterápiás Klinika, Szeged \\ ${ }^{4}$ Szegedi Tudományegyetem, II. sz. Belgyógyászati Klinika és Kardiológiai Központ, \\ Hematológia osztály, Szeged
}

\begin{abstract}
Bevezetés: Korábbi tanulmányok kimutatták, hogy a krónikus limfocitás leukémiában (CLL) szenvedő betegek körében a melanoma malignum (MM) kialakulásának kockázata nagyobb az átlagpopulációhoz viszonyítva. Amennyiben a melanoma a krónikus limfocitás leukémia diagnózisának felállítását követően alakul ki, rosszabb túlélésre lehet számítani, mint amikor a krónikus limfocitás leukémiát megelőzi. Jelen vizsgálatunk célja az volt, hogy a két malignus megbetegedés együttes előfordulása esetén a betegeket azonosítsuk, majd a kórtörténetben szereplő adatokat elemezzük, és a betegségek kórlefolyását megvizsgáljuk a szakirodalomban fellelhető korábbi tanulmányok tükrében. Betegek és módszerek: Retrospektív adatgyüjtés során a 2000 és 2016 közötti időszakban 947 krónikus limfocitás leukémiás beteg adatainak áttekintése során összesen 13 betegnél igazolódott krónikus limfocitás leukémia és melanoma malignum együttes előfordulása a Szegedi Tudományegyetemen. Eredmények: 11 esetben a krónikus limfocitás leukémia diagnózisa megelőzte a melanoma malignum diagnózisát, 1 esetben a melanoma malignum volt az első diagnózis, 1 esetben pedig egy időben került felismerésre a két betegség. Diagnózisok közt eltelt idő 7,4 év. 5 beteg részesült fludarabintartalmú kezelésben. Következtetés: A krónikus limfocitás leukémiás betegeink 1,3\%-ában észleltük melanoma fennállását. Ezekben a betegekben a melanoma malignum diagnózisának felállításáig eltelt átlagos időtartamot nem befolyásolta, hogy a kezelés tartalmazott-e fludarabint. Az alacsony betegszám alapján a túlélésre vonatkozóan csak óvatos következtetést lehet levonni. Mindkét malignus betegség együttes fennállása esetén fontosnak tartjuk az interdiszciplináris együttmúködés hangsúlyozását.
\end{abstract}

Kulcsszavak: krónikus limfocitás leukémia, melanoma malignum, immunszuppresszió, fludarabin

\section{Malignant melanoma in our patients with chronic lymphocytic leukemia}

Background: Previous studies have shown that the risk of developing malignant melanoma (MM) in chronic lymphocytic leukemia (CLL) patients is higher than in the average population. Furthermore, the survival of those patients who have been diagnosed with chronic lymphocytic leukemia prior to malignant melanoma is worse, compared to individuals with chronic lymphocytic leukemia following malignant melanoma. The aim of this study is to analyze the data of patients' history and to investigate the course of their illness comparing to previous findings in the literature. Methods: Retrospective data collection at University of Szeged between 2000 and 2016 resulted in the occurrence of both chronic lymphocytic leukemia and malignant melanoma in 13 cases. Results: In 11 cases chronic lymphocytic leukemia was the first diagnosis, in one case the malignant melanoma was diagnosed prior to chronic lymphocytic leukemia, and in one case both diseases got diagnosed at the same time. The time elapsed between the two diagnoses was 7.4 years. Five patients got therapy that contained fludarabin. Conclusions: Among chronic lymphocytic leukemia patients the malignant melanoma occurrence was $1.3 \%$. Contrary to the literature data, malignant melanoma did not occur earlier in patients treated with fludarabine than in non-treated patients. We can not make conclusions regarding the survival, because of the low number of cases. Our interdisciplinary cooperation is important in patients diagnosed with both chronic lymphocytic leukemia and malignant melanoma.

@ Levelezési cím: Dr. Korom Ágnes, Szegedi Tudományegyetem, II. sz. Belgyógyászati Klinika és Kardiológiai Központ, 6725 Szeged, Semmelweis u. 8; E-mail: korom.agnes@med.u-szeged.hu 
Keywords: chronic lymphocytic leukemia (leukemia, lymphocytic, chronic, B-cell), malignant melanoma, immunosuppression, fludarabine

(Beérkezett: 2019. szeptember 16.; elfogadva: 2019. november 10.)

\section{Rövidítések}

${ }^{18} \mathrm{~F}$-FDG = 2-deoxi-2-( $\left.{ }^{18} \mathrm{~F}\right)$-fluoro-D-glükóz; Bcl-2 = B-sejt limfóma-2; BNO = Betegségek nemzetközi osztályozása; CLL = Krónikus limfocitás leukémia; CT = Komputertomográfia; $\mathrm{ICI}=$ Immun checkpoint inhibitor; $\mathrm{MM}=$ Melanoma malignum; nHL = Non-Hodgkin-limfóma; OS = Overall survival, teljes túlélés; PET-CT = Pozitron emissziós tomográfia-CT; $\mathrm{UV}=$ ultraviola-, ultraibolya sugárzás; $\mathrm{WHO}=$ World Health Organization

\section{Bevezetés}

A bőrdaganatok (basalioma, laphámrák, melanoma malignum) a leggyakoribb másodlagos rosszindulatú elváltozások a krónikus limfocitás leukémiában (CLL) szenvedő betegekben [1]. Azon túl, hogy a bőrdaganatok incidenciája magasabb a CLL-s betegek körében, megfigyelték, hogy a melanoma malignum lefolyása, mortalitása is kedvezőtlenebb a nem CLL-s populációhoz viszonyítva. Azoknál a betegeknél, akiknél a melanoma került elsőként diagnosztizálásra, majd azt követően a CLL, a túlélésben szignifikáns eltérés nem volt kimutatható az átlagpopulációhoz viszonyítva [2]. Ez azzal is magyarázható, hogy amennyiben a MM felszínesen terjedő, és kimetszéssel maradéktalanul eltüntethető, nem befolyásolja a CLL lefolyását.

A CLL-s betegekben megjelenő melanoma kialakulásának hátterében számos mechanizmus ismert, és felvetődik a CLL mint betegség, illetve a kezelésében alkalmazott szerek immunszuppresszív hatása, valamint a genetikai háttér [3, 4].

CLL-ban károsodik mind a sejtes, mind a humorális immunválasz. A T-sejtek CD40 ligandjának csökkent kifejeződése következtében károsodik az antigénbemutatás, és csökken az immunoglobulintermelés, különösen az IgG- és az IgA-szintek alacsonyak. A MM kialakulásában is fontos szerep jut az immunrendszernek, mivel a sejtes immunválasz a citotoxikus CD8+ T-sejtek által történő citokinek felszabadítása révén, a humorális immunválasz pedig a CD4+ T-helper sejtek indukálta IgG antitesttermeléssel lépnek fel a rosszindulatú sejtek ellen. CLL-ban e folyamatok károsodása hozzájárulhat a melanoma kialakulásához. A CLL-terápiában használatos kemoimmunoterápiás szereknek is szerepe lehet a második malignus betegség kialakulásában. Ennek hátterében részben az immunszuppresszív hatásuk állhat, másrészt befolyásolhatják a DNS-javító mechanizmusokat, illetve új mutációk kialakulását is eredményezhetik. A rituximab valószínúleg további immunszuppresszív hatása miatt jelenthet kockázatot a melanoma kialakulására. Egy korábbi vizsgálatban azt találták, hogy a CLL-ban szenvedő betegek között a melanoma incidenciája magasabb volt azoknál, akik fludarabinkezelésben részesültek [4].

A közös genetikai háttér nem bizonyított CLL és MM esetén, azonban a Bcl-2 onkogén fokozott kifejeződése megfigyelhető egyes CLL és MM esetekben. A Bcl-2-nek az apoptosis gátlásában van szerepe. Egy tanulmány szerint a BRAF-mutációk a CLL-s betegek 2,8\%-ában fordultak elő, azonban BRAF-inhibitorok és MEK-gátló szerek in vitro nem voltak hatással a CLL-s sejtekre [5]. A MM kialakulásában szerepet tulajdonítanak az UV-sugárzásnak, azonban a CLL kialakulásában nem ismert a szerepe.

\section{Betegek és módszerek}

A retrospektív vizsgálatot etikai engedély (114/2017SZTE) birtokában indítottuk. A betegeket az eMedSolution rendszerben elérhető BNO-kódok alapján azonosítottuk. A 2000.01.01. és 2016.12.31 közötti időszakban 947 beteg jelent meg a Szegedi Tudományegyetem II. sz. Belgyógyászati Klinika és Kardiológia Központ Hematológia részlegén, akiknél CLL diagnózisa fennállt. E betegek között 13 esetben szerepelt a dokumentációban a CLL BNO kódja (C9110) mellett a MM BNO kódja (C4300-4390, D0300-D0390). A részletes adatok az eMedSolution rendszerben található hematológiai dokumentációból kerültek kigyüjtésre.

A túlélési statisztikák az IBM SPSS Software 22 verziójának segítségével készültek.

\section{Eredmények}

A Szegedi Tudományegyetem Hematológiai részlegén 2000 és 2016 között gondozott CLL-s betegek között (947 beteg) a melanoma incidenciája $1,3 \%$ volt.

A betegcsoportban férfi dominanciát láttunk (10 férfi: 77\%, 3 nő: 23\%). A két malignus betegség diagnózisának felállítása között átlagosan 7,4 év telt el. Az átlagos életkor a CLL diagnózisakor 64,3 év, míg a MM diagnózisakor 67,9 év volt. A legtöbb esetben (11 beteg) a CLL került elsőként felismerésre, 2 esetben előzte meg a melanoma felismerése a CLL diagnózisát. 
1. tábázat. Összefoglaló táblázat

\begin{tabular}{|c|c|c|}
\hline Összefoglaló táblázat & & Megjegyzés \\
\hline CLL-MM is előfordul & 13 eset & \\
\hline Átlagéletkor CLL dg-kor & 64,31 év & \\
\hline Átlagéletkor MM dg-kor & 67,92 év & \\
\hline Első diagnózis & 11 esetben CLL & 1 esetben MM, 1 esetben egyidőben kerül felismerésre \\
\hline Összes MM-előfordulás & $18 \mathrm{db}$ & 4 esetben ugyanabban évben, 1 esetben 6 év eltérés \\
\hline CLL stádium & $\begin{array}{l}\text { Rai sz. alacsony: } 5 \\
\text { Rai sz. közepes: } 7 \\
\text { Rai sz. magas: } 1\end{array}$ & \\
\hline Diagnózisok közt eltelt idő átlagosan & 7,384 év & \\
\hline Férfi/nő arány & $\begin{array}{l}\text { Férfi: } 10 \\
\text { Nő: } 3\end{array}$ & \\
\hline Lokalizáció & $\begin{array}{l}\text { Fej-nyak: } 3 \\
\text { Törzs: } 9 \\
\text { Felső végtag: } 4 \\
\text { Alsó végtag: } 2\end{array}$ & \\
\hline Breslow-féle tumorvastagság & Átlag: 1.509 & $\begin{array}{l}\text { Max.: 6,764 } \\
\text { Min.: in situ }(0,000)\end{array}$ \\
\hline Patológiai tumor staging & $\begin{array}{l}\text { In situ: } 5 \\
1 \mathrm{a}: 2 \\
\text { 1b: } 4 \\
\text { 2a: } 3 \\
\text { 2b: } 0 \\
3 \mathrm{a}: 0 \\
\text { 3b: } 1 \\
\text { 4a: } 0 \\
\text { 4b: } 3\end{array}$ & \\
\hline MM stádium & $\begin{array}{l}\text { (0. st) in situ: } 5 \\
\text { IA: } 2 \\
\text { IB: } 7 \\
\text { II: } 0 \\
\text { III: } 3 \\
\text { IV: } 1\end{array}$ & \\
\hline CLL-kezelés (Fludarabin) & $\begin{array}{l}\text { Kapott: } 5 \\
\text { Nem részesült: } 8\end{array}$ & \\
\hline
\end{tabular}

A Rai szerinti rizikócsoportok alapján diagnóziskor a CLL 5 esetben az alacsony rizikócsoportba, 7 esetben a közepes és 1 esetben a magas kockázati csoportba tartozott. A betegcsoportban a CLL lefolyása során 5 esetben volt szükség kemoimmunoterápiás kezelésre, a terápiás kombináció minden esetben tartalmazott fludarabint is. Ezekben az esetekben a CLL volt az elsőként felismert betegség. A fludarabintartalmú kombinált kezelésben részesült betegek esetében a CLL diagnosztizálását követően a MM kialakulásáig eltelt idő átlagosan 7,2 év, míg azokban a betegekben, akik ilyen kezelésben nem részesültek 7,5 év. Az átlagos túlélés a kezelt betegek esetén 156 hónap, míg a CLL-s kezelést nem kapott eseteknél 121 hónap volt.

A 13 betegnél összesen 18 db melanomás elváltozás került felismerésre és szövettani feldolgozásra, 4 betegnél fordult elő egynél több melanomás elváltozás, 3 esetben ugyanabban az évben, egy esetben a két MM felismerése között 6 év telt el. A MM-nál a stádiumba sorolásnál fontosak a primer tumor egyes paraméterei, a nyirokcsomókban, a bőrön és egyéb szervekben jelentkező áttétek. A primer tumor vonatkozásában prognosztikai tényező a tumor Breslow szerinti vastagsága és az ulceráció jelenléte. Nagy általánosságban korai felfedezésnek minősül, ha nyirokcsomó és belszervi áttétek nincsenek, és a primer tumor $1 \mathrm{~mm}$-nél vékonyabb és nem ulcerált. 13 esetből 6-nál a melanoma tumorvastagsága $1 \mathrm{~mm}$ felett volt, mely késői felismerésre utal, a betegek a MM diagnózisát követően 3 éven belül elhunytak (min. 1 év, max. 3 év). A MM leggyakrabban a törzsön és a végtagokon fordult elő.

Minthogy a betegek adatainak feldolgozása 2001-ben kezdődött, citogenetikai vizsgálat nem történt rutinszerüen ezekben az esetekben. Mindkét csoportban 1-1 esetben történt FISH-vizsgálat. Egy betegnél 11q deléció (ATM gén delécióval) igazolódott, egyéb citogenetikai 
eltérés (6q deléció, 12-es triszómia, 13q deléció, 17p deléció) nem volt kimutatható. Egy másik betegnél biallélikus és monoallélikus $13 q$ deléció volt igazolható, egyéb citogenetikai eltérés nem volt detektálható.

A 2 éves túlélés $85 \%$, az 5 éves túlélés $60 \%$, a 10 éves túlélés $51 \%$ volt. Az átlagos túlélés (median survival) a betegcsoportban 141 hónap volt. Fontosnak tartjuk megjegyezni, hogy az alacsony betegszám óvatosságra int a konklúzió tekintetében.

\section{Megbeszélés}

A fellelhető szakirodalmak többsége a CLL-s és nHL-s betegek körében kialakult MM előfordulási gyakoriságát vizsgálta a nem CLL-s/nem nHL-s populációhoz viszonyítva és a túlélést a CLL-s betegek körében MM-mal vagy anélkül hasonlította össze $[1,2,6]$. Irodalmi adatok alapján a CLL-s betegek körében a MM incidenciája 1,5\% volt, míg retrospektív vizsgálatunkban 1,3\%. Olsen és munkatársai által végzett metaanalízis során a melanoma kialakulásának rizikója CLL-s betegekben 3,88-szorosnak bizonyult az átlagpopulációhoz viszonyítva [20].

Az esetek többségében a CLL alakult ki először, melyet követett a MM diagnózisa. Famenini és munkatársai tanulmányában azok a betegek, akiknél a melanoma megjelenése előtt a CLL már fennállt, 1,46-szor nagyobb halálozási kockázatnak voltak kitéve a nem CLL-s populációhoz viszonyítva a melanomájuk miatt [1]. Ennek hátterében a CLL miatti immunszuppresszió állhat. Nem találtak különbséget a kockázatot illetően azoknál a betegeknél, akiknél a MM megelőzte a CLL diagnózisát. Ennek oka feltehetően az lehet, hogy a MM-ot korai stádiumban diagnosztizálták, amikor a malignus betegség sebészi kimetszéssel kezelhető, és jó a prognózisa. A nemek aránya a betegcsoportban a CLL-s populációhoz hasonlóan alakult férfi dominanciával.

A diagnózisok felállítása között eltelt átlagos időtartam 7,4 év volt. Egy esetben a két diagnózis között 18 év telt el (ez volt a legmagasabb érték). A CLL-val gondozott betegnél a melanoma pT4b stádiumú volt felismeréskor, és a nyirokcsomók is érintettek voltak. A későbbiekben a MM agyi áttéteket okozott. A beteg a MM diagnózisát követően 2 éven belül hunyt el feltehetően az intracraniális metasztázisok következtében kialakult szövődmények miatt. Egy másik beteg esetében a két melanoma egyidőben került felismerésre, melyet 1 hónappal később a CLL diagnózisa követett. Ennél az esetnél a melanoma szintén IV. stádiumú volt, DTIC- (dacarbazin-) terápiára is sor került, azonban a beteg 1 éven belül elhunyt. A két kiemelt eset közül egyikük sem részesült CLL-s kemoterápiás kezelésben.

Kevés irodalmi adat áll rendelkezésre a CLL-s betegpopulációban a metasztatikus melanoma kezelésére alkalmazott immun check point inhibitorok (ICI) hatékonyságáról. Néhány CLL-s beteg esetében, amikor a melanoma kezelésére PD-1-gátlót alkalmaztak, a megfigyelt időszakban nem észleltek progressziót CLL-t illetően [18]. Egy kisebb betegcsoportban is alkalmaztak ICI-t (PD-1 gátló pembrolizumabot), ezekben az esetekben transzformálódott betegség esetén volt megfigyelhető pozitív válasz a kezelésre [19].

Az irodalmi adatok szerint a CLL-s betegeknél a MM magasabb előfordulási gyakoriságát figyelték meg, amennyiben a kezelés fludarabint tartalmazott [9]. Nem ismert a konkrét mechanizmus, mely a melanoma kialakulását indukálná. A háttérben a fludarabin immunszuppresszív és DNS-károsító hatását feltételezik. Arról, hogy a fludarabintartalmú kezelés befolyásolja-e a túlélést a melanomás betegekben, a szakirodalomban nem volt fellelhető tanulmány. Vizsgálatunkban 3 év különbséget észleltünk a túlélésben a fludarabinterápiában részesülő, illetve nem részesülő két alcsoport között, azonban további vizsgálatok szükségesek ezen összefüggés tisztázására.

A túlélési analízis során meghatározásra kerültek a 2, 5 és a 10 éves túlélések. Brewer és munkatársai 2012-es kutatásában a MM diagnózisáig átlagosan 2,7 év telt el (interkvartilis terjedelem 0,5 és 6,2 év), míg vizsgálatunkban a CLL-s betegek MM diagnózisáig eltelt idő ennél hosszabb volt, átlagosan 7,4 év (interkvartilis terjedelem 0,1 és 18 év) [2].

2. tábázat. Túlélési adatok (Kaplan-Meier-féle analízis, 95\%-os konfidenciaintervallum)

\begin{tabular}{ll}
\hline Túlélés & CLL-MM (13 beteg) \\
\hline 2 éves (\%) & 85 \\
5 éves (\%) & 60 \\
10 éves (\%) & 51 \\
\hline átlagos (median & $\begin{array}{l}141 \text { hónap } \\
\text { survival) }\end{array}$ \\
& $\begin{array}{c}\text { - Fludarabinkezelésben részesülö } \\
(n=5): 121 \text { hónap }\end{array}$ \\
& - Nem részesülő $(n=8): 156$ hónap \\
\hline
\end{tabular}

A két malignus betegség együttes fennállása kihívást jelent a diagnosztika és a kezelés szempontjából egyaránt. Megnagyobbodott nyirokcsomókat mind MM-ban, mind CLL-ban láthatunk, mely differenciáldiagnosztikai problémát jelenthet. A szakirodalomban néhány esetet írnak le, ahol ugyanaz a nyirokcsomó a CLL és az MM által is érintett $[10,11]$. A képalkotó vizsgálatok közül a PETCT-t a magas rizikójú (primer tumor kifekélyesedése, magas mitotikus index, limfovaszkuláris invázió) melanomás esetekben áttétek kutatására használják, de segíthet annak a megítélésében is, hogy a nyirokcsomó melanomára vagy inkább CLL-ra gyanús, ugyanis míg a melanomás nyirokcsomó általában intenzíven halmozza a ${ }^{18}$ F-FDG-radiofarmakont, addig a nHL-k, köztük a CLL az egyik legkevésbé ${ }^{18} \mathrm{~F}-\mathrm{FDG}$ avid [12]. Biztos diagnózist azonban a szövettani vizsgálat nyújt. 


\section{Következtetések}

Előfordulás tekintetében intézményünkben a CLL-s betegek körében 1,3\%-ban észleltünk MM-ot. A melanoma kialakulásáig eltelt idő nem mutatott összefüggést azzal, hogy fludarabint tartalmazott-e a kezelés vagy sem. Az alacsony betegszám miatt a statisztikai eredmények kellő körültekintéssel értékelhetők.

A két betegség együttes fennállása esetén a pontos diagnózis felállításához, a betegség kiterjedtségének megállapításához, az optimális terápia megválasztásához és a relapszusok hatékony ellátásához a bőrgyógyászonkológus és a hematológus szakorvos szoros együttmüködése nélkülözhetetlen. A két betegség diagnosztikája és a kezelése komoly kihívást jelent a tapasztalt szakemberek számára is. A bőrdaganatok esetében cél a korai felismerés, mely alapvetően befolyásolja a betegek túlélését. Ehhez a betegek tájékoztatása és a rendszeres önvizsgálat szükséges. Mivel a CLL-ban szenvedő betegek fokozottan veszélyeztetettek bőrtumorok kialakulására, ezért rendszeres bőrgyógyászati szürésük javasolt.

Nyilatkozat: A közlemény más folyóiratban korábban nem jelent meg, és máshová nem került beküldésre. A levelező szerző elolvasta a szerzői útmutatót.

Érdekeltségek: A szerzőknek nincsenek érdekeltségeik. Anyagi támogatás: A közlemény megírása anyagi támogatásban nem részesült.

Szerzői munkamegosztás: K.Á., Cs.I. - adatgyűjtés, adatok feldolgozása; B.Z., O.J., G.P.T., B.E. - irodalom-áttekintés, szakmai felügyelet; K.Á., Cs.I., B.E., G.P.T - kézirat szövegének megírása. A cikk végleges változatát valamenynyi szerző elolvasta és jóváhagyta.

\section{Irodalom}

[1] Famenini S, Martires KJ, Zhou H, et al. Melanoma in patients with chronic lymphocytic leukemia and non-Hodgkin lymphoma. J Am Acad Dermatol. 2015; 72(1): 78-84.

[2] Brewer JD, Shanafelt TD, Otley CC, et al. Chronic lymphocytic leukemia is associated with decreased survival of patients with malignant melanoma and merkel cell carcinoma in a SEER population-based study. J Clin Oncol. 2012; 30(8): 843-849.

[3] Brewer JD, Habermann TM, Shanafelt TD. Lymphoma-associated skin cancer: incidence, natural history, and clinical management. Int J Dermatol. 2014; 53(3): 267-274.
[4] Lam CJK, Curtis RE, Dores GM, et al. Risk factors for melanoma among survivors of non-Hodgkin lymphoma. J Clin Oncol. 2015; 33(28): 3096-3104

[5] Michael B, Jebaraj C, Kienle D, et al. BRAF mutations in chronic lymphocytic leukemia. Leuk Lymphoma 2013; 54(6): 1177-1182.

[6] Brewer JD, Shanafelt TD, Call TG, et al. Increased incidence of malignant melanoma and other rare cutaneous cancers in the setting of chronic lymphocytic leukemia. Int J Dermatol. 2015; 54(8): 287-293.

[7] Megahed M, Schön M, Selimovic D, et al. Reliability of diagnosis of melanoma in situ. Lancet. 2002; 359(9321): 1921-1922.

[8] Catovsky D, Wade R, Else M. The clinical significance of patients' sex in chronic lymphocytic leukemia. Haematologica 2014; 99(6): 1088-1094.

[9] Lam CJK, Curtis RE, Dores GM, et al. Risk factors for melanoma among survivors of non-Hodgkin lymphoma. J Clin Oncol. 2015; 33(28): 3096-3104.

[10] Cantor AS, Moschos S, Jukic DM. A principal case of multiple lymphoid collision tumors involving both B-cell chronic lymphocytic leukemia and metastatic malignant melanoma. Dermatol Online J. $2010 ; 16(7): 6$.

[11] Farma JM, Zager JS, Barnica-elvir V, et al. A collision of diseases: Chronic lymphocytic leukemia discovered during lymph node biopsy for melanoma. Ann Surg Oncol. 2013; 20(4): 1360-1364.

[12] Gero D, Queiros da Mota V, Boubaker A, et al. Accuracy of sentinel lymph node dissection for melanoma staging in the presence of a collision tumour with a lymphoproliferative disease. Melanoma Res. 2014; 24(4): 371-376.

[13] International CLL-IPI Working Group. An international prognostic index for patients with chronic lymphocytic leukaemia (CLLIPI): a meta-analysis of individual patient data. Lancet Oncol. 2016; 17(6): 779-790.

[14] Molica, S. Second neoplasms in chronic lymphocytic leukemia: incidence and pathogenesis with emphasis on the role of different therapies. Leuk Lymphoma 2005; 46(1): 49-54.

[15] Morton LM, Curtis RE, Linet MS, et al. Second malignancy risks after non-Hodgkin's lymphoma and chronic lymphocytic leukemia: differences by lymphoma subtype. J Clin Oncol. 2010 Nov 20; 28(33): 4935-4944.

[16] Sacchi S, Marcheselli L, Bari A, et al. Secondary malignancies after treatment for indolent non-Hodgkin's lymphoma: a 16-year follow-up study. Haematologica 2008; 93(3): 398-404.

[17] Wiernik PH, et al. Second neoplasms in patients with chronic lymphocytic leukemia. Curr Treat Options Oncol. 2004; 5(3): 215223.

[18] Archibald WJ, Meacham PJ, Williams ALM, et al. Management of melanoma in patients with chronic lymphocytic leukemia. Leuk Res. 2018; 71; 43-46.

[19] Ding W, LaPlant BR, Call TG et al., Pembrolizumab in patinets with CLL and Richter transformation or with relapsed CLL. Blood 2017; 129, 3419-3427.

[20] Olsen CM, Lane SW, Green AC. Increased risk of melanoma in patients with chronic lymphocytic leukaemia. Melanoma Res. 2016; 26(2): 188-194.

A cikk a Creative Commons Attribution 4.0 International License (https://creativecommons.org/licenses/by/4.0/) feltételei szerint publikált Open Access közlemény, melynek szellemében a cikk bármilyen médiumban szabadon felhasználható, megosztható és újraközölhető, feltéve, hogy az eredeti szerző és a közlés helye, illetve a CC License linkje és az esetlegesen végrehajtott módosítások feltüntetésre kerülnek. (SID_1) 